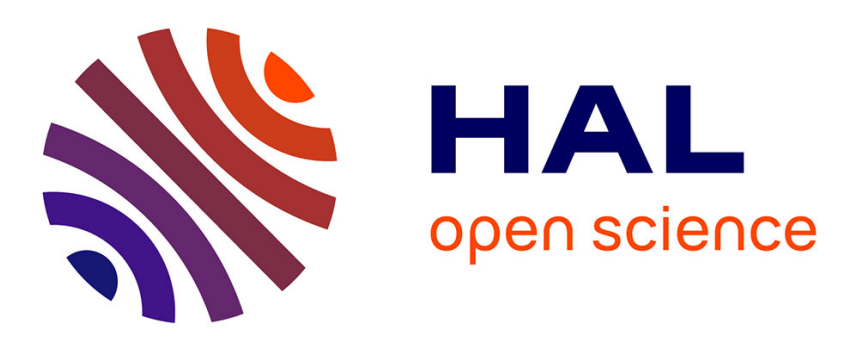

\title{
Absorption and emission spectra of $\mathrm{U} 4+$ diluted in the incommensurate structure of $\mathrm{ThCl} 4$
}

C. Khan Malek, J.C. Krupa, P. Delamoye, M. Genet

\section{To cite this version:}

C. Khan Malek, J.C. Krupa, P. Delamoye, M. Genet. Absorption and emission spectra of U4 + diluted in the incommensurate structure of ThCl4. Journal de Physique, 1986, 47 (10), pp.1763-1773. 10.1051/jphys:0198600470100176300 . jpa-00210372

\section{HAL Id: jpa-00210372 https://hal.science/jpa-00210372}

Submitted on 1 Jan 1986

HAL is a multi-disciplinary open access archive for the deposit and dissemination of scientific research documents, whether they are published or not. The documents may come from teaching and research institutions in France or abroad, or from public or private research centers.
L'archive ouverte pluridisciplinaire HAL, est destinée au dépôt et à la diffusion de documents scientifiques de niveau recherche, publiés ou non, émanant des établissements d'enseignement et de recherche français ou étrangers, des laboratoires publics ou privés. 


\title{
Absorption and emission spectra of $\mathrm{U}^{4+}$ diluted in the incommensurate structure of $\mathrm{ThCl}_{4}$
}

\author{
C. Khan Malek, J. C. Krupa, P. Delamoye and M. Genet \\ Laboratoire de Radiochimie, Institut de Physique Nucléaire, Université Paris-Sud, 91406 Orsay France
}

(Reçu le 11 avril 1986, accepté le 9 juin 1986)

\begin{abstract}
Résumé. - Les spectres d'absorption et de fluorescence de $\mathrm{U}^{4+}$ dilué dans des monocristaux de $\mathrm{ThCl}_{4}$ ont été mesurés de $4,2 \mathrm{~K}$ jusqu'à la température ambiante. Les cristaux de $\beta-\mathrm{ThCl}_{4}$ présentent une structure incommensurable en dessous de $70 \mathrm{~K}$ avec une perte de la périodicité le long de l'axe c. Ceci a pour conséquence une variation de la distance métal-halogène lorsqu'on passe d'une maille à l'autre. La symétrie du site de l'ion actinide est ainsi abaissée. Les raies correspondant au site de symétries $\mathrm{S}_{4}$ et $\mathrm{D}_{2}$ ont été identifiées par spectroscopie. La symétrie $S_{4}$ a été ramenée à celle de $D_{2 d}$ et une analyse paramétrique des niveaux d'énergie de $\mathrm{U}^{4+}$ en symétrie $\mathrm{D}_{2 \mathrm{~d}}$ et $\mathrm{D}_{2}$ est donnée. Pour 25 niveaux dans le site $\mathrm{D}_{2 \mathrm{~d}}$, l'écart quadratique moyen $\sigma$ est de $46 \mathrm{~cm}^{-1}$ et de $56 \mathrm{~cm}^{-1}$ pour les 34 niveaux en symétrie $\mathrm{D}_{2}$. Les paramètres qui interviennent dans les calculs pour les deux symétries sont légèrement différents.
\end{abstract}

\begin{abstract}
The absorption and fluorescence spectra of $\mathrm{U}^{4+}$ diluted in single crystals of $\mathrm{ThCl}_{4}$ have been measured at temperatures ranging from $4.2 \mathrm{~K}$ to room temperature. $\beta$ - $\mathrm{ThCl}_{4}$ exhibits on incommensurate structure below $70 \mathrm{~K}$ with a loss of periodicity along the $\mathbf{c}$ axis. This results in a variation of the distance between the metal and the halogen from one cell to another. The site symmetry of the actinide ions is then reduced. The lines corresponding to the sites of the resulting symmetries $S_{4}$ and $D_{2}$ are identified spectroscopically. The $S_{4}$ symmetry is approximated by the $D_{2 d}$ one and a parametric analysis of the energy levels of $U^{4}$ in the $D_{2 d}$ and $D_{2}$ symmetries is reported. For 25 levels in the $D_{2 d}$ site the root mean square deviation $\sigma$ is $46 \mathrm{~cm}^{-1}$ and for 34 levels in $\mathrm{D}_{2}, \sigma=56 \mathrm{~cm}^{-1}$. The parameters which occur in both symmetries are only slightly changed.
\end{abstract}

\section{Introduction.}

There has recently been some interest shown in the studies of the tetravalent uranium ion $\mathrm{U}^{4}+\left(5 \mathrm{f}^{2}\right)$ in solid state matrices that started with the new parametric analysis of $\mathrm{U}^{4+}$ in $\beta-\mathrm{ThBr}_{4}[1]\left(\mathrm{U}^{4+}\right.$ at a site of $D_{2 d}$ or $D_{2}$ symmetry) followed by a reinterpretation of the spectra of $\mathrm{U}^{4+}$ in the borohydrides [2] with the $\mathrm{U}^{4+}$ ion at a site of $\mathrm{T}_{\mathrm{d}}$ symmetry. The study of $\mathrm{U}^{4}+$ in $\mathrm{ThCl}_{4}$ brings a new set of spectroscopic parameters for $\mathrm{U}^{4+}$ at a site of relatively high symmetry $\left(D_{2 d}\right)$ which can be compared to those obtained in the bromide matrix $\mathrm{ThBr}_{4}$. Both matrices offer a similar dodecahedron of coordination for the $\mathrm{U}^{4+}$ ion and like $\mathrm{ThBr}_{4}$ [3], $\mathrm{ThCl}_{4}$ undergoes a second order displacive phase transition at a temperature $T_{\mathrm{c}}=70 \mathrm{k}$. Below $T_{\mathrm{c}}$, neutron diffraction experiments revealed that the crystal structure of $\mathrm{ThCl}_{4}$ is incommensurate and modulated [4], due to transverse displacements of the chloride ions perpendicular to the c axis of the crystals. These displacements are different in each unit cell and they can be described as in $\mathrm{ThBr}_{4}$ in terms of a local phase $\varphi_{1}$, where 1 is the index which identifies the cell [5]. The modulation reduces the site symmetry of the actinide ion that is $D_{2 d}$ at room temperature and $S_{4}, D_{2}, C_{2}$ at low temperature, according the $\varphi_{1}$ values :

for $\varphi_{1}=0$, the symmetry of the site is $S_{4}$, for $\varphi_{1}= \pm \pi / 2$, the $\mathrm{U}^{4+}$ sites are described by the $\mathrm{D}_{2}$ symmetry,

for $0<\left|\varphi_{1}\right|<\pi / 2$, the sites are described by the $\mathrm{C}_{2}$ symmetry.

There exists a continuous variation of the environment, thus of the crystal field around the $\mathrm{U}^{4+}$ ion and consequently the energy levels of $\mathrm{U}^{4+}$ are modulated between two extreme positions corresponding to $\varphi_{1}=0$ and $\varphi_{1}= \pm \pi / 2$ for a $\pi$ band and $\varphi_{1}= \pm \pi / 2$ for a $\sigma$ band. The shapes of these bands 
are then characteristic (Fig. 1). They are described by the model of Delamoye and Currat [5] as a continuum of lines limited by two sharp edges. They correspond to the sites of $D_{2}$ symmetry ( $\sigma$ band) or $S_{4}$ and $D_{2}$ symmetries for a $\pi$ band. Site selective excitation of the $\mathrm{U}^{4+}$ absorption levels permitted us to correlate the absorption and emission lines [6] and in particular to identify transitions of $\mathrm{U}^{4+}$ ions at sites of $D_{2}$ and $S_{4}$ symmetries. Therefore we are in a position to analyse the $\mathrm{U}^{4+}$ energy levels in these both sites.
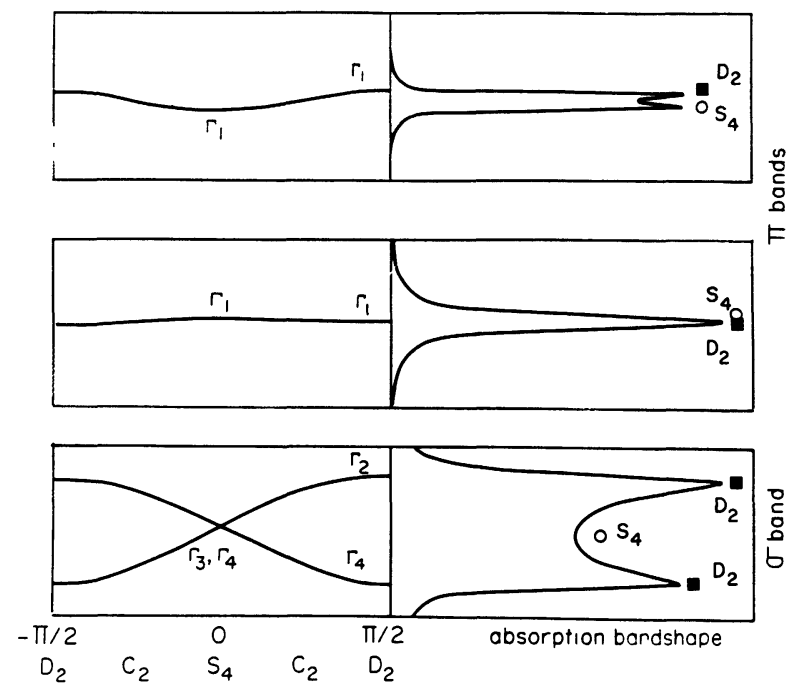

Fig. 1. $-\mathrm{U}^{4+}$ absorption bandshapes in the incommensurate structure of $\mathrm{ThCl}_{4}$.

\section{Experimental details and analysis of the data.}

$\beta-\mathrm{ThCl}_{4}$ single crystals were grown by the Bridgman method [7]. The crystal structure is tetragonal [8] space group $\mathrm{I}_{1} /$ amd at room temperature ( $\beta$ form of $\mathrm{ThCl}_{4}$ [9]). $\mathrm{ThCl}_{4}$ was doped with about $0.1 \%$ of $\mathrm{U}^{4+}$, the doping material being $\mathrm{UO}_{2}$ or $\mathrm{UCl}_{4}$. The crystals were cleaved and polished in a dry box because of their hygroscopicity and they were sealed under a helium atmosphere (300 torrs) in silica tubes. The crystals used for the measurements were about $15 \times 3 \times 5 \mathrm{~mm}^{3}$ or smaller. They presented a cleavage face which was not exactly perpendicular to the fourfold axis so they can be oriented in order to take polarized spectra $\sigma$ and $\sigma+\pi$. Experiments at low temperature were performed in an Oxford Instruments helium gas circulating cryostat.

The absorption and emission spectra were recorded at different temperatures between $4.2 \mathrm{~K}$ and $300 \mathrm{~K}$ in the visible and infrared region $(0.3 \mu \mathrm{m}-2.5 \mu \mathrm{m})$ on a one meter HR 1000 Jobin Yvon spectrometer. It is equipped in the visible region with a 1200 lines $/ \mathrm{mm}$ grating and a photomultiplier, and in the infrared with a 600 lines $/ \mathrm{mm}$ and a $\mathrm{PbS}$ detector. The calibration was made with a low pressure mercury lamp before and after the recording of the spectrum. Fluorescence spectra were excited with a Sopra nitrogen pumped dye laser.

The surrounding of the $\mathrm{U}^{4+}$ ions in the different symmetries mentioned before is non-centrosymmetric (non-inversion centre), so strong zero phonon transitions are expected. All spectra were analysed with a linear polarizer which can be oriented in both parallel and perpendicular directions relative to the $\mathbf{C}_{4}$ optical axis which is preserved below the phase transition temperature in the tetragonal structure of the incommensurate phase. The $\sigma$ and $\alpha$ spectra were checked to be identical, thus leaving us only with electric dipole transition to deal with. Though the polarization is expected to be complete $(\pi$ or $\sigma(\alpha)$ ) (for definition see Table I), the $\sigma+\pi$ were recorded instead of the pure $\pi$ spectra, which is due to a slight misorientation regarding the $\mathrm{C}_{4}$ axis on the various crystals that were studied.

Table I. - Electric dipole selection rules in the $\mathrm{D}_{2 \mathrm{~d}}(a)$, $\mathrm{S}_{4}(b)$ and $\mathrm{D}_{2}(c)$ symmetries, notations from Nielson and Koster [11]. A $\sigma$ polarization corresponds to a spectrum recorded with the electric field $\mathbf{E}$ perpendicular to the principal axis $\mathrm{C}_{4}$ whereas a $\pi$ spectrum corresponds to $\mathbf{E}$ parallel to this axis.

a) $\rightarrow$

\begin{tabular}{c|ccccc}
$\mathrm{D}_{2 \mathrm{~d}}$ & $\Gamma_{1}$ & $\Gamma_{2}$ & $\Gamma_{3}$ & $\Gamma_{4}$ & $\Gamma_{5}$ \\
\hline$\Gamma_{1}$ & & & & $\pi$ & $\sigma$ \\
$\Gamma_{2}$ & & & $\pi$ & & $\sigma$ \\
$\Gamma_{3}$ & & $\pi$ & & & $\sigma$ \\
$\Gamma_{4}$ & $\pi$ & & & & $\sigma$ \\
$\Gamma_{5}$ & $\sigma$ & $\sigma$ & $\sigma$ & $\sigma$ & $\pi$
\end{tabular}

b) $\rightarrow$

\begin{tabular}{c|ccc}
$\mathrm{S}_{4}$ & $\Gamma_{1}$ & $\Gamma_{2}$ & $\Gamma_{3}, \Gamma_{4}\left(^{*}\right)$ \\
\hline$\Gamma_{1}$ & & $\pi$ & $\sigma$ \\
$\Gamma_{2}$ & $\pi$ & & $\sigma$ \\
$\Gamma_{3}, \Gamma_{4}\left(^{*}\right)$ & $\sigma$ & $\sigma$ & $\pi$
\end{tabular}

(*) $\Gamma_{3}$ and $\Gamma_{4}$ are pseudo-degenerate levels (same energy).

\begin{tabular}{cc|cccc} 
& $\mathrm{D}_{2}$ & $\Gamma_{1}$ & $\Gamma_{2}$ & $\Gamma_{3}$ & $\Gamma_{4}$ \\
\hline & $\Gamma_{1}$ & & $\sigma$ & $\pi$ & $\sigma$ \\
& $\Gamma_{2}$ & $\sigma$ & & $\sigma$ & $\pi$ \\
& $\Gamma_{3}$ & $\pi$ & $\sigma$ & & $\sigma$ \\
& $\Gamma_{4}$ & $\sigma$ & $\pi$ & $\sigma$ &
\end{tabular}

Some $75 \%$ of the lines can be seen with the $\sigma$ polarization and the lines observed with a $\pi$ polarization are generally weaker than those with a $\sigma$ polarization (Fig. 2). This trend has also been seen on $\mathrm{ThSiO}_{4}-\mathrm{U}^{4+}[10]$ where the $\mathrm{U}^{+4}$ ion is at a site of $\mathrm{D}_{2 \mathrm{~d}}$ symmetry as well. The lines in $\beta-\mathrm{ThCl}_{4}-\mathrm{U}^{4+}$ with a polarization $\sigma$ are in general 
broader than those with the polarization $\pi$. This has been explained by the Delamoye and Currat's analysis [5] of the line shapes recorded in $\beta-\mathrm{ThBr}_{4}-\mathrm{U}^{4+}$. The width of the lines in $\mathrm{ThCl}_{4}-\mathrm{U}^{4+}$ are broader overall than those in $\mathrm{ThSiO}_{4}-\mathrm{U}^{4+}$ which offers a regular $\mathrm{D}_{2 \mathrm{~d}}$ site for $\mathrm{U}^{4}+$ at low temperature.
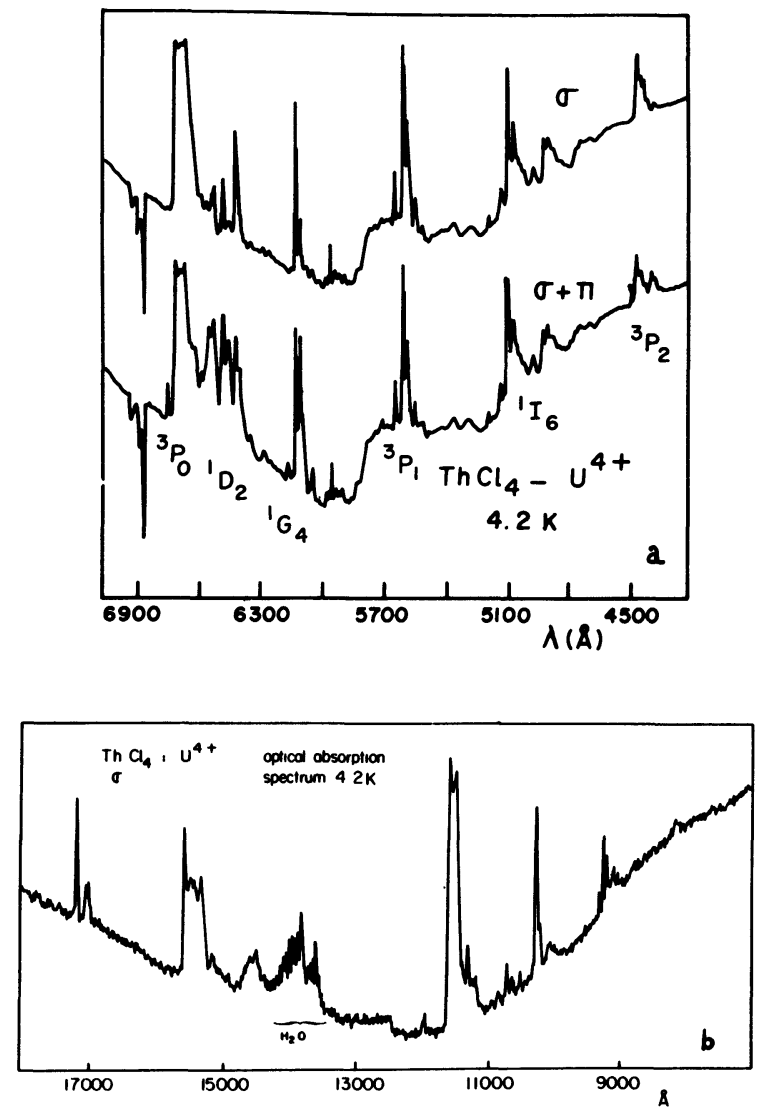

Fig. 2. - Absorption spectra of $\mathrm{ThCl}_{4}-\mathrm{U}^{4+}$ in the visible (a) and IR (b).

Although in the modulated structure of $\beta-\mathrm{ThCl}_{4}$ the symmetry of the actinide site is lowered $\left(S_{4}-C_{2}-D_{2}\right)$, we shall us the $D_{2 d}$ designation in the labelling of the energy levels. It can be noted that the electric dipole selection rules for the $D_{2 d}$ and $S_{4}$ (subgroup of $D_{2 d}$ ) groups [11] only differ for the transitions (Table I) :

$$
\begin{gathered}
\Gamma_{3} \leftrightarrow \Gamma_{1} \\
\Gamma_{2} \leftrightarrow \Gamma_{4}
\end{gathered}
$$$$
\left(D_{2}\right)
$$

that are forbidden in the $\mathrm{D}_{2 \mathrm{~d}}$ symmetry and allowed with a $\pi$ polarization in the $\mathrm{S}_{4}$ symmetry as $\Gamma_{1} \rightarrow \Gamma_{2}$ transitions.

The other selection rules are the same.
In the $\mathrm{S}_{4}$ symmetry the loss of symmetry elements is responsible for the introduction of imaginary terms in the crystal field hamiltonian, $\operatorname{Im~} \mathrm{B}_{4}^{4}$ and Im $B_{4}^{6}$, whereas all the crystal field parameters are real in the $\mathrm{D}_{2 \mathrm{~d}}$ symmetry (Table II). Interpreting the data in the $D_{2 d}$ symmetry instead of in the $S_{4}$ symmetry results in neglecting these imaginary terms in the even rank crystal field components that are used for the calculations of the energy levels of the optically active ions. Nevertheless the use of the $\mathrm{D}_{2 \mathrm{~d}}$ symmetry in place of the $\mathrm{S}_{4}$ symmetry should give us the main features of the spectra. Esterowitz et al. [12] had already noticed with $\mathrm{Pr}^{3}+$ doped in $\mathrm{LiYF}_{4}$ at a site of $\mathrm{S}_{4}$ symmetry that the use of the $\mathrm{D}_{2 \mathrm{~d}}$ selection rules was a good approximation in identifying energy levels. Hence the $\mathrm{D}_{2 \mathrm{~d}}$ symmetry will be considered in our case. The crystal field eigenstates carry the $\Gamma_{1}$ through $\Gamma_{5}$ irreducible representations associated with the $\mathrm{D}_{2 \mathrm{~d}}$ site symmetry. Only the $\Gamma_{5}$ representation is doubly degenerate, the remaining $\Gamma_{1}$ to $\Gamma_{4}$ being non degenerate. The lowering of the symmetry from $D_{2 d}$ to $D_{2}$ lifts the degeneracy of the $\Gamma_{5}$ levels of energy. Thus there are only singlets carrying the $\Gamma_{1}$ to $\Gamma_{4}$ point group representations associated with the $\mathrm{D}_{2}$ symmetry. The correspondance between the sets of representations are in the $\mathrm{D}_{2 \mathrm{~d}}, \mathrm{~S}_{4}$ and $\mathrm{D}_{2}$ symmetries shown in table III. The selection rules for the electric dipole transitions for the $D_{2 d}$ and $D_{2}$ symmetries are given in the table $I$.

Table II. - Crystal field parameters of even rank in the $\mathrm{D}_{2 \mathrm{~d}}(\mathrm{a}), \mathrm{S}_{4}(\mathrm{~b})$ and $\mathrm{D}_{2}$ (c) symmetries.
a) $D_{2 d}$ symmetry
b) $\mathrm{S}_{4}$ symmetry
c) $\mathrm{D}_{2}$ symmetry
$\mathrm{B}_{0}^{2}, \mathrm{~B}_{0}^{4}, \mathrm{~B}_{0}^{6}$
$\mathrm{~B}_{4}^{4}, \mathrm{~B}_{4}^{6}$
$\mathrm{B}_{0}^{2}, \mathrm{~B}_{0}^{4}, \mathrm{~B}_{0}^{6}$
$\mathrm{~B}_{4}^{4}+\mathrm{iB}_{4}^{4}$
$\mathrm{~B}_{4}^{6}+\mathrm{iB}_{4}^{6}$
$\mathrm{B}_{0}^{2^{\prime}}, \mathrm{B}_{2}^{2^{\prime}}$
$\mathrm{B}_{0}^{4^{\prime}}, \quad \mathrm{B}_{2}^{4^{\prime}}, \quad \mathrm{B}_{4}^{4^{\prime}}$
$\mathrm{B}_{0}^{6^{\prime}}, \quad \mathrm{B}_{2}^{6^{\prime}}, \quad \mathrm{B}_{4}^{6^{\prime}}, \quad \mathrm{B}_{6}^{6^{\prime}}$

Table III. - Correspondence between the sets of representations in the $\mathrm{D}_{2 \mathrm{~d}}, \mathrm{~S}_{4}$ and $\mathrm{D}_{2}$ symmetries [11].

\begin{tabular}{l|ll}
$\mathrm{D}_{2 \mathrm{~d}}$ & $\mathrm{~S}_{4}$ & $\mathrm{D}_{2}$ \\
\hline$\Gamma_{1}$ & $\Gamma_{1}$ & $\Gamma_{1}$ \\
$\Gamma_{2}$ & $\Gamma_{1}$ & $\Gamma_{3}$ \\
$\Gamma_{3}$ & $\Gamma_{2}$ & $\Gamma_{1}$ \\
$\Gamma_{4}$ & $\Gamma_{2}$ & $\Gamma_{3}$ \\
$\Gamma_{5}$ & $\Gamma_{3}+\Gamma_{4}$ & $\Gamma_{2}+\Gamma_{4}$
\end{tabular}

Following the study of $\mathrm{U}^{4+}$ in $\beta-\mathrm{ThBr}_{4}$ on which Zeeman and M.C.D. studies were performed [13], the ground state level is assumed to be a $\left(\mathrm{D}_{2 \mathrm{~d}}\right) \Gamma_{4}$ level, which is consistent with our interpretation of 
the crystal field transitions. At $4.2 \mathrm{~K}$ the $\sigma$ lines correspond to transitions from the $\left(\mathrm{D}_{2 \mathrm{~d}}\right) \Gamma_{4}$ ground state to the doubly degenerate $\left(\mathrm{D}_{2 \mathrm{~d}}\right) \Gamma_{5}$ levels of energy while the lines recorded with the $\pi$ polarization correspond to transitions to the $\left(D_{2 d}\right) \Gamma_{1}$ non degenerate levels of energy.

In the most intense peaks a contribution of $\mathrm{U}^{4+}$ ions at a site of $\mathrm{D}_{2 \mathrm{~d}}$ symmetry is expected. Indeed the intensity of the electric dipole transitions in the same configuration and regardless of the site symmetry of the ion, is proportional to matrix elements involving the crystal field parameters of odd rank $\left(B^{* k} q\right)^{2}$.

The $D_{2}$ symmetry is close to the $D_{2 d}$ symmetry at low temperature so the additional parameters $B_{4}^{* 5^{\prime}}, B_{4}^{* 7^{\prime \prime}}$ and $B_{6}^{* 7^{\prime \prime}}$ to be added to the odd rank parameters for the $\mathrm{D}_{2 \mathrm{~d}}$ symmetry $\left(B_{2}^{* 3}, B_{2}^{* 5}\right.$ and $B_{2}^{* 7}$ ) can be supposed to be weak. Therefore the intensity of the lines corresponding to the $\mathrm{U}^{4+}$ ions in the $D_{2 d}$ and $D_{2}$ symmetries will follow the same trend.

There are more lines than are theoretically expected from a $\Gamma_{4}$ ground state, even if some additional lines are assumed to come from $\mathrm{U}^{4+}$ ions at sites of $\mathrm{D}_{2}$ and $\mathrm{C}_{2}$ symmetries alone according to the selection rules. Some lines are vibronic in origin and they are found on the blue side of the electronic lines at $4.2 \mathrm{~K}$. When excited they give the same fluorescence spectra as the electronic lines they are associated with. Some other lines are probably due to an impurity or to $\mathrm{U}^{3+}$. In $\beta-\mathrm{ThBr}_{4}-\mathrm{U}^{4+}$, M.C.D. experiments [13] showed an anomalously high $g$ value for certain lines that are attributed to impurities.

At higher temperature transitions from a lowlying level at $55 \mathrm{~cm}^{-1}$ are readily apparent. This level has also been seen in fluorescence experiments [6]. It can be interpreted as a $D_{2}$ level arising from the splitting of the first excited Stark level representated by $\Gamma_{5}$ in the $\mathrm{D}_{2 \mathrm{~d}}$ symmetry. The shape of the bands in $\beta-\mathrm{ThCl}_{4}-U^{4+}$ is modified when the temperature is increased (Fig. 3). In particular the sharp edges corresponding to transitions of the $\mathrm{U}^{4+}$ ions at sites of $\mathrm{D}_{2}$ symmetry decrease in intensity. Those edge singularities finally disappear and the $\mathrm{D}_{2 \mathrm{~d}}$ line is left alone at $70 \mathrm{~K}$. With increasing concentration of $\mathrm{U}^{4+}$ a decrease in the sharp edges is also observed.

The fluorescence spectrum of $\mathrm{U}^{4+}$ in the solid state is reported here for the third time. It had already been exhibited in $\mathrm{ThBr}_{4}-\mathrm{U}^{4+}$ [14] and in $\mathrm{Cs}_{2} \mathrm{ZrBr}_{6}-\mathrm{U}^{4+}[15]$. At $4.2 \mathrm{~K}$ with the halogen lamp as excitation source two broad features at $5131 \AA$ and $6870 \AA$ are observed. They correspond to the radiative transitions between the levels: ${ }^{1} \mathrm{I}_{6} \rightarrow{ }^{3} \mathrm{H}_{4}$ and ${ }^{1} \mathrm{D}_{2} \rightarrow{ }^{3} \mathrm{H}_{4}$ respectively. Those emission

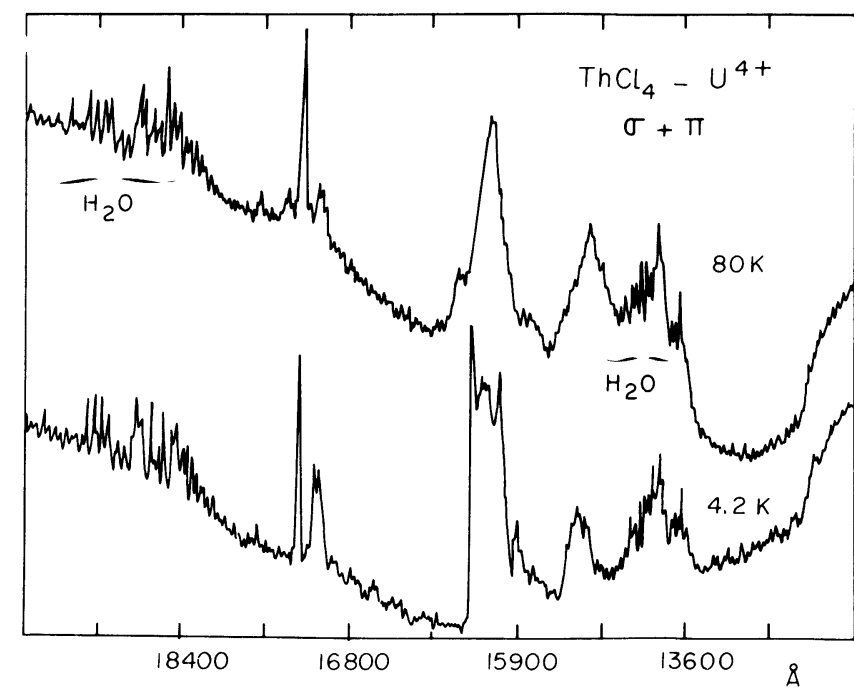

Fig. 3. - Absorption spectra of $\mathrm{ThCl}_{4}-\mathrm{U}^{4+}$ above and below the phase transition temperature.

lines are strongly dependent on temperature and the energy of the exciting radiation. The results of some site selective excitation experiments at $4.2 \mathrm{~K}$ are given in table IV, with their assignment.

Dye laser excitation experiments were performed in the absorption bands in the visible region in order to identify the lines corresponding respectively to the $D_{2 d}$ and $D_{2}$ symmetries. Indeed, the induced green and red fluorescence permitted us to correlate the observed transitions and attribute a definite symmetry to the $\mathrm{U}^{4+}$ from which they originate [6]. In the I.R. region where no fluorescence was observed, the middle of the absorption band was taken as corresponding to the $D_{2 d}$ both in the $\sigma$ and $\pi$ spectra. The levels to be taken into account in the I.R. for the $D_{2}$ symmetry are the limiting lines of the bands in the $\sigma$ spectrum and the middle of the bands in the $\pi$ spectrum. The error committed by doing so should not be very large, at least in the spectra where the $\pi$ lines are much narrower than those observed in the $\sigma$ polarization [5].

\section{Calculations and discussion.}

The levels were fitted by simultaneous diagonalization of the free ion, $\widehat{H}_{0}$, and crystal field Hamiltonians $\widehat{H}_{\mathrm{cc}}+\widehat{H}_{\mathrm{cc}}[16]$ :

$$
\widehat{H}=\widehat{H}_{0}+\widehat{H}_{\mathrm{cc}}+\widehat{H}_{\mathrm{cc}}
$$

where $\widehat{H}_{0}$ is characterized by the parameters of :

- interelectronic repulsion $F^{k}, k=2,4,6$

- spin-orbit coupling $\zeta$

- configuration interaction $\alpha, \beta$ and $\gamma$

plus the $P^{k}(k=2,4,6)$ and $M^{k}(k=0,2,4)$ parameters describing respectively the electrostatically correlated spin-orbit $\left(P^{k}\right)$, spin-spin and spinother orbit $\left(M^{k}\right)$ interactions. 
Table IV. - Emission spectrum of $\mathrm{ThCl}_{4}-\mathrm{U}^{4+}$ at $4.2 \mathrm{~K}$.

a) 000, 00, $0:$ strong lines in order of decreasing intensity.

b) $* * *, * *, *$ : very weak lines in order of decreasing intensity.

\begin{tabular}{|c|c|c|c|}
\hline \multicolumn{2}{|c|}{$\begin{array}{c}\mathrm{D}_{2 \mathrm{~d}} \\
\lambda_{\mathrm{exc}}=5112.1 \AA \\
\left(19556 \mathrm{~cm}^{-1}\right)\end{array}$} & \multicolumn{2}{|c|}{$\begin{array}{c}\mathrm{D}_{2} \\
\lambda_{\mathrm{exc}}=5116.5 \AA \\
\left(19539 \mathrm{~cm}^{-1}\right)\end{array}$} \\
\hline$\AA$ & $\mathrm{cm}^{-1}$ & $\AA$ & $\mathrm{cm}^{-1}$ \\
\hline \multicolumn{4}{|c|}{${ }^{1} \mathrm{D}_{2} \rightarrow{ }^{3} \mathrm{H}_{4}$} \\
\hline $\begin{array}{r}0006896 \\
006931 \\
* * 6945 \\
* 6974 \\
* * 6982 \\
* 6994 \\
* 7207\end{array}$ & $\begin{array}{l}14498 \\
14424 \\
14395 \\
14335 \\
14319 \\
14294 \\
13872\end{array}$ & $\begin{array}{r}0006870 \\
06899 \\
006930 \\
* 6955 \\
* 6974 \\
\text { *** } 7216\end{array}$ & $\begin{array}{l}14552 \\
14491 \\
14426 \\
14374 \\
14335\end{array}$ \\
\hline \multicolumn{4}{|c|}{${ }^{1} I_{6} \rightarrow{ }^{3} F_{2}$} \\
\hline $\begin{array}{r}* * 6519 \\
* 6536 \\
* 6565 \\
* * 6610\end{array}$ & $\begin{array}{l}15336 \\
15296 \\
15228 \\
15124\end{array}$ & $\begin{array}{r}* 6515 \\
* * 6543 \\
* 6563 \\
* * 6603 \\
* * 6610\end{array}$ & $\begin{array}{ll}15 & 345 \\
15279 \\
15233 \\
15140 \\
15124\end{array}$ \\
\hline \multicolumn{4}{|c|}{${ }^{1} \mathrm{I}_{6} \rightarrow{ }^{3} \mathrm{H}_{4}$} \\
\hline $\begin{array}{rrr}000 & 5 & 142 \\
0 & 5 & 147 \\
* * * & 5 & 378 \\
* * & 5 & 383 \\
* * & 5 & 433 \\
* * & 5 & 464 \\
* * & 5 & 519\end{array}$ & 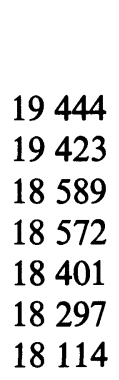 & $\begin{array}{rrr}0 & 5 & 116 \\
000 & 5 & 131 \\
0 & 5 & 146 \\
0 & 5 & 151\end{array}$ & $\begin{array}{l}19541 \\
19484 \\
19427 \\
19408\end{array}$ \\
\hline
\end{tabular}

$\widehat{H}_{\mathrm{cc}}$ corresponds to the crystal field Hamiltonian that includes the parameters of the same rank $k$ and multiplicity $q$ for the $\mathrm{D}_{2 \mathrm{~d}}$ and $\mathrm{D}_{2}$ symmetries. The supplementary parameters to be added in the case of the $\mathrm{D}_{2}$ symmetry are taken into account in $\widehat{H}_{\mathrm{cc}}$, which is considered to be a perturbation of $H_{\mathrm{cc}}$, due to the low magnitude of the crystal field modulation. $B_{0}^{2}, B_{0}^{4}, B_{4}^{4}, B_{0}^{6}$ and $B_{4}^{6}$, parametrize the action of $\widehat{H}_{\mathrm{cc}}$ in the $\mathrm{D}_{2 \mathrm{~d}}$ symmetry, and $B_{0}^{2^{\prime}}, B_{0}^{4^{\prime}}, B_{4}^{4^{\prime}}, B_{0}^{6^{\prime}}$ and $B_{4}^{6^{\prime}}$ parametrize the main effect of $\widehat{H}_{\mathrm{cc}}$ in the $\mathrm{D}_{2}$ symmetry, with the perturbation to the lowering of symmetry being taken into account by the additional $D_{2}$ parameters $B_{2}^{2^{\prime}}, B_{2}^{4^{\prime}}, B_{6}^{6^{\prime}}$ on which is built $\widehat{H}_{\mathrm{cc}}^{\prime}$.

\section{Fitting in the $D_{\mathbf{2}}$ and $D_{\mathbf{2}}$ symmetries.}

4.1. $D_{2 d}$ SYMMETRY CALCULATIONS. - The starting values for the various parameters were taken from $\mathrm{U}^{4+}$ in $\beta-\mathrm{ThBr}_{4}[1]$ and the $B_{q}^{k}$ were varied till a reasonable fit was obtained. Then both the free ion parameters $F^{k}$ and $\zeta$, and the crystal field parameters $B_{q}^{k}$ were varied. In a last step the configuration interaction parameters $\alpha$ and $\beta$ were allowed to vary but the parameter $\gamma$ was fixed at the value found in $\mathrm{ThBr}_{4}-\mathrm{U}^{4}+[1]$, because the position of the ${ }^{1} \mathrm{~S}_{0}$ which fixes, with the ${ }^{3} \mathrm{P}_{0}$, the $\gamma$ value is not known. The $P^{k}$ and $M^{k}$ were left as well at the values in $\mathrm{ThBr}_{4}-\mathrm{U}^{4+}$.

An r.m.s. deviation $\sigma$ of $46 \mathrm{~cm}^{-1}$ was obtained for 25 experimental levels. The spectroscopic parameters corresponding to this last fit are listed in table $\mathrm{V}$ and the observed and calculated energy levels along with the $\mathrm{U}^{4+}$ eigenvectors in the $\mathrm{D}_{2 \mathrm{~d}}$ symmetry are given in table VI. This table shows the fluorescing level of the singlet ${ }^{1} I_{6}$ above the energy gap ${ }^{1} I_{6}-{ }^{3} P_{1}$. However the agreement between the experimental and calculated levels is overall satisfactory.

4.2. $\mathrm{D}_{2}$ SYMmETRY CAlCUlations. - Since the effects of the incommensurate structure which lowers the symmetry from $D_{2 d}$ to $D_{2}$ are presumed to be small, we adopted the same procedure as was used for $\mathrm{ThBr}_{4}-\mathrm{U}^{4+}[1]$ in order to determine the $\mathrm{D}_{2}$ crystal field parameters. In a first step, the $\mathrm{D}_{2}$ levels were treated as $\mathrm{D}_{2 \mathrm{~d}}$ by fixing the $F^{k}$ and $\zeta$ parameters and fitting those which are common to $D_{2 d}$ and $D_{2}$ symmetries to the $\left(D_{2}\right) \Gamma_{1}$ levels and to the centers of gravity of $\Gamma_{2}-\Gamma_{4}$ pairs $\left(\Gamma_{5}\right.$ in $\left.D_{2 d}\right)$. Then each experimental $\Gamma_{2}-\Gamma_{4}$ pair was adjusted to reproduce the calculated centers of gravity so that the variation of the $B_{q}^{k^{\prime}}$ parameters would fit only the $\Gamma_{2}-\Gamma_{4}$ splitting. With these parameters as initial values, the Slater parameters, the spin-orbit constant $\zeta$, and all of the crystal-field parameters were allowed to vary.

For 34 levels, the r.m.s. deviation was $56 \mathrm{~cm}^{-1}$. The parameters (Table V) common to $D_{2 d}$ and $D_{2}$ symmetries have close values and the additional parameters are all small in both symmetries. The results are reported in tables V and VII.

\section{Discussion.}

We used the crystal field model to successfully interpret the energy levels of $\mathrm{U}^{4+}$ in the sites of approximate $\mathrm{D}_{2 \mathrm{~d}}$ and $\mathrm{D}_{2}$ symmetry in the incommensurately modulated structure of $\beta-\mathrm{ThCl}_{4}$. Both the large spin-orbit and crystal field interactions result in an effective $J$-mixing in the $\mathrm{U}^{4+}$ eigenvectors. The Auzel and Malta's parameter [17] :

$$
\frac{N_{v}}{\sqrt{4 \pi}}=\left(\sum_{k} \frac{1}{2 k+1}\left(B_{q}^{k}\right)^{2}\right)^{1 / 2}
$$


Table V. - Spectroscopic parameters of $\mathrm{U}^{4+}$ (in - the r.m.s. deviation $\sigma$ is :

$\mathrm{cm}^{-1}$ )

- Uv : free ion

- $\mathrm{U}^{4+}$ : in the borohydrides in $\mathrm{T}_{\mathrm{d}}$ symmetry

- $\mathrm{U}^{4+}$ in $\mathrm{ThX} 4$ in $\mathrm{D}_{2 \mathrm{~d}}$ and $\mathrm{D}_{2}$ symmetries

$$
\sigma=\left(\sum_{i}\left(E_{\mathrm{obs} .}^{i}-E_{\mathrm{calc} .}^{i}\right)^{2} / n-m\right)^{1 / 2}
$$

where $n$ is the number of observed levels and $m$ the number of parameters varied.

in $\mathrm{D}_{2 \mathrm{~d}}$ symmetry

in $\mathrm{D}_{2}$ symmetry

\begin{tabular}{|c|c|c|c|c|c|c|}
\hline $\begin{array}{c}\text { Spectro- } \\
\text { scopic } \\
\text { parameters }\end{array}$ & Uv (19) & $\begin{array}{c}\mathrm{U}\left(\mathrm{BD}_{4}\right)_{4} \\
\text { in } \mathrm{Hf}\left(\mathrm{BD}_{4}\right)_{4} \\
(2)\end{array}$ & $\begin{array}{c}\mathrm{ThBr}_{4}-\mathrm{U}^{4+} \\
\text { (1) }\end{array}$ & $\mathrm{ThCl}_{4}-\mathrm{U}^{4+}$ & $\begin{array}{c}\mathrm{ThBr}_{4}-\mathrm{U}^{4+} \\
\text { (1) }\end{array}$ & $\mathrm{ThCl}_{4}-\mathrm{U}^{4+}$ \\
\hline$F^{2}$ & $51938 \pm 39$ & $41121 \pm 236$ & $42253 \pm 127$ & $42752 \pm 162$ & $42264 \pm 84$ & $42736 \pm 175$ \\
\hline$F^{4}$ & $42708 \pm 100$ & $38849 \pm 1071$ & $40458 \pm 489$ & $39925 \pm 502$ & $41159 \pm 407$ & $39821 \pm 589$ \\
\hline$F^{6}$ & $27748 \pm 68$ & $21711 \pm 827$ & $25891 \pm 383$ & $24519 \pm 479$ & $26018 \pm 237$ & $24438 \pm 470$ \\
\hline$\zeta$ & $1968 \pm 2$ & $1807 \pm 16$ & $1783 \pm 7$ & $1808 \pm 8$ & $1774 \pm 5$ & $1805 \pm 9$ \\
\hline$\alpha$ & $33.5 \pm 0.4$ & $40 \pm 3$ & $31 \pm 1$ & $30.4 \pm 2$ & (31) & $31.6 \pm 2.2$ \\
\hline$\beta$ & $-644 \pm 25$ & $(-648)$ & $-644 \pm 75$ & $-492 \pm 84$ & (644) & $(-492)$ \\
\hline$\gamma$ & $744 \pm 26$ & $\left(\begin{array}{ll}1 & 200\end{array}\right)$ & $\left(\begin{array}{ll}1 & 200\end{array}\right)$ & $\left(\begin{array}{ll}1 & 200\end{array}\right)$ & $\left(\begin{array}{ll}1 & 200\end{array}\right)$ & $\left(\begin{array}{ll}1 & 200)\end{array}\right.$ \\
\hline$M^{0}$ & & $(0.99)$ & $(0.99)$ & $(0.99)$ & (0.99) & $(0.99)$ \\
\hline$M^{2}$ & & $(0.55)$ & $(0.55)$ & $(0.55)$ & $(0.55)$ & $(0.55)$ \\
\hline$M^{4}$ & & $(0.38)$ & $(0.38)$ & $(0.38)$ & $(0.38)$ & $(0.38)$ \\
\hline$P^{2}$ & $573(66)$ & $(500)$ & $(500)$ & $(500)$ & $(500)$ & $(500)$ \\
\hline$P^{4}$ & $524(144)$ & $(500)$ & $(500)$ & $(500)$ & $(500)$ & $(500)$ \\
\hline$P^{6}$ & $1173(321)$ & $(500)$ & $(500)$ & $(500)$ & $(500)$ & $(500)$ \\
\hline$B_{0}^{2}$ & & & $1096 \pm 80$ & $-1054 \pm 117$ & $-1108 \pm 65$ & $-1037 \pm 137$ \\
\hline$B_{0}^{4}$ & & $-2486 \pm 170$ & $1316 \pm 146$ & $1146 \pm 200$ & $1358 \pm 137$ & $1121 \pm 303$ \\
\hline$B_{4}^{4}$ & & & $-2230 \pm 85$ & $-2767 \pm 147$ & $-2219 \pm 76$ & $-2948 \pm 169$ \\
\hline$B_{0}^{6}$ & & $-5287 \pm 113$ & $-3170 \pm 379$ & $-2135 \pm 404$ & $-3458 \pm 267$ & $-2120 \pm 419$ \\
\hline$B_{4}^{6}$ & & & $686 \pm 246$ & $-312 \pm 227$ & $694 \pm 195$ & $-315 \pm 356$ \\
\hline$B_{2}^{2}$ & & & & & $-78 \pm 30$ & $-77 \pm 48$ \\
\hline$B_{2}^{4}$ & & & & & $318 \pm 122$ & $356 \pm 167$ \\
\hline$B_{2}^{6}$ & . & & & & $136 \pm 101$ & $158 \pm 171$ \\
\hline$B_{6}^{6}$ & & & & & $123 \pm 125$ & $424 \pm 220$ \\
\hline$n$ & 13 & 19 & 26 & 25 & 38 & 34 \\
\hline$\sigma$ & 10 & 71 & 36 & 46 & 39 & 56 \\
\hline
\end{tabular}


Table VI. - Calculated and experimental energy levels of $\mathrm{ThCl}_{4}: \mathrm{U}^{4+}$ in $\mathrm{D}_{2 \mathrm{~d}}$ symmetry with the main components (in squared \%) of the corresponding eigenvectors.

\begin{tabular}{|c|c|c|c|c|c|}
\hline$\Gamma$ & $E_{\text {calc. }}\left(\mathrm{cm}^{-1}\right)$ & $E_{\text {obs. }}\left(\mathrm{cm}^{-1}\right)$ & $\Delta E\left(\mathrm{~cm}^{-1}\right)$ & $g_{\text {calc. }}$ & Eigenvectors $\left({ }^{\times}\right)$ \\
\hline 4 & 0 & 0 & 0 & & $89 \%{ }^{3} \mathrm{H}_{4}+8 \%{ }^{1} \mathrm{G}_{4}$ \\
\hline 5 & 148 & $112\left(^{*}\right)$ & 36 & 0,49 & $87 \%{ }^{3} \mathrm{H}_{4}+9 \%{ }^{1} \mathrm{G}_{4}$ \\
\hline 1 & 219 & & & & $80 \%{ }^{3} \mathrm{H}_{4}+11 \%{ }^{1} \mathrm{G}_{4}$ \\
\hline 2 & 805 & & & & $89 \%{ }^{3} \mathrm{H}_{4}+9 \%{ }^{1} \mathrm{G}_{4}$ \\
\hline 1 & 907 & & & & $88 \%{ }^{3} \mathrm{H}_{4}+4 \%{ }^{1} \mathrm{G}_{4}$ \\
\hline 3 & 986 & & & & $92 \%{ }^{3} \mathrm{H}_{4}+8 \%{ }^{1} \mathrm{G}_{4}$ \\
\hline 5 & 1144 & & & 3,50 & $89 \%{ }^{3} \mathrm{~F}_{2}+9 \%{ }^{1} \mathrm{D}_{2}$ \\
\hline 3 & 3821 & & & & $81 \%{ }^{3} \mathrm{~F}_{2}+16 \%{ }^{1} \mathrm{D}_{2}$ \\
\hline 5 & 4000 & & & $-1,62$ & $76 \%{ }^{3} F_{2}+13 \%{ }^{1} D_{2}$ \\
\hline 4 & 4108 & & & & $85 \%{ }^{3} \mathrm{~F}_{2}+12 \%{ }^{1} \mathrm{D}_{2}$ \\
\hline 1 & 4255 & $4220(*)$ & 35 & & $81 \%{ }^{3} F_{2}+13 \%{ }^{1} D_{2}$ \\
\hline 3 & 5706 & & & & $97 \%{ }^{3} \mathrm{H}_{5}+2 \%{ }^{3} \mathrm{~F}_{3}$ \\
\hline 5 & 5810 & 5815 & -5 & $-0,60$ & $93 \%{ }^{3} \mathrm{H}_{5}+2 \%{ }^{3} \mathrm{~F}_{2}$ \\
\hline 2 & 5864 & & & & $96 \%{ }^{3} \mathrm{H}_{5}+2 \%{ }^{3} \mathrm{~F}_{3}$ \\
\hline 5 & 6388 & 6430 & -42 & 0,74 & $95 \%{ }^{3} \mathrm{H}_{5}+2 \%{ }^{3} \mathrm{~F}_{2}$ \\
\hline 4 & 6389 & & & & $95 \%{ }^{3} \mathrm{H}_{5}$ \\
\hline 5 & 6609 & & & $-6,11$ & $94 \%{ }^{3} \mathrm{H}_{5}+4 \%{ }^{3} \mathrm{~F}_{2}$ \\
\hline 1 & $\begin{array}{l}6629 \\
6693\end{array}$ & 6589 & 40 & & $96 \%{ }^{3} \mathrm{H}_{5}+4 \%{ }^{3} \mathrm{~F}_{3}$ \\
\hline $\begin{array}{l}2 \\
4\end{array}$ & $\begin{array}{l}6693 \\
8424\end{array}$ & & & & $80 \%{ }^{3} \mathrm{~F}_{3}+7 \%^{3} \mathrm{~F}_{4}$ \\
\hline 5 & 8476 & 8470 & 6 & 5,94 & $91 \%{ }^{3} F_{3}+3 \%{ }^{3} F_{4}$ \\
\hline 3 & 8543 & & & & $91 \%{ }^{3} \mathrm{~F}_{3}+6 \%{ }^{3} \mathrm{H}_{6}$ \\
\hline 2 & 8605 & & & & $82 \%{ }^{3} \mathrm{~F}_{3}+6 \%{ }^{3} \mathrm{~F}_{4}+6 \%{ }^{3} \mathrm{H}_{5}$ \\
\hline 5 & 8677 & 8666 & 11 & $-1,07$ & $81 \%{ }^{3} \mathrm{~F}_{3}+5 \%{ }^{3} \mathrm{~F}_{4}+5 \%{ }^{3} \mathrm{H}_{6}$ \\
\hline 1 & 8844 & 8843 & 1 & & $44 \%{ }^{3} \mathrm{~F}_{4}+39 \%{ }^{1} \mathrm{G}_{4}$ \\
\hline 5 & 8991 & & & 0,26 & $41 \%{ }^{3} \mathrm{~F}_{4}+33 \%{ }^{1} \mathrm{G}_{4}$ \\
\hline 3 & 9041 & & & & $47 \%{ }^{3} \mathrm{~F}_{4}+26 \%{ }^{1} \mathrm{G}_{4}$ \\
\hline 2 & 9297 & & & & $49 \%{ }^{3} \mathrm{~F}_{4}+31 \%{ }^{1} \mathrm{G}_{4}$ \\
\hline 1 & 9441 & 9405 & 36 & & $55 \%{ }^{3} \mathrm{~F}_{4}+33 \%{ }^{1} \mathrm{G}_{4}$ \\
\hline 3 & 9653 & & & & $56 \%{ }^{3} \mathrm{~F}_{4}+31 \%{ }^{1} \mathrm{G}_{4}$ \\
\hline 5 & 9677 & 9749 & -72 & 3,38 & $51 \%{ }^{3} \mathrm{~F}_{4}+32 \%{ }^{1} \mathrm{G}_{4}$ \\
\hline 4 & 10752 & & & & $83 \%{ }^{3} \mathrm{H}_{6}+6 \%{ }^{1} \mathrm{G}_{4}$ \\
\hline 5 & 10790 & 10820 & -30 & 1,38 & $86 \%{ }^{3} \mathrm{H}_{6}+4 \%{ }^{1} \mathrm{I}_{6}+4 \%{ }^{1} \mathrm{G}_{4}$ \\
\hline 1 & 10803 & 10752 & 51 & & $93 \%{ }^{3} \mathrm{H}_{6}+4 \%{ }^{1} \mathrm{I}_{6}$ \\
\hline 3 & 11239 & & & & $90 \%{ }^{3} \mathrm{H}_{6}+6 \%{ }^{1} \mathrm{I}_{6}$ \\
\hline 5 & 11324 & & & 1,99 & $90 \%{ }^{3} \mathrm{H}_{6}+7 \%{ }^{1} \mathrm{I}_{6}$ \\
\hline 4 & 11357 & & & & $87 \%{ }^{3} \mathrm{H}_{6}+5 \%{ }^{1} \mathrm{I}_{6}$ \\
\hline 2 & 11369 & & & & $92 \%{ }^{3} \mathrm{H}_{6}+7 \%{ }^{1} \mathrm{I}_{6}$ \\
\hline 3 & 11423 & & & & $88 \%{ }^{3} \mathrm{H}_{6}+4 \%{ }^{1} \mathrm{I}_{6}$ \\
\hline 1 & 11676 & & & & $86 \%{ }^{3} \mathrm{H}_{6}+7 \%^{1}{ }^{1} \mathrm{I}_{6}$ \\
\hline 5 & 11872 & & & $-10,19$ & $88 \%{ }^{3} \mathrm{H}_{6}+6 \%^{1} \mathrm{I}_{6}$ \\
\hline 3 & 14650 & 14610 & 40 & & $52 \%{ }^{1} \mathrm{D}_{2}+27 \%{ }^{3} \mathrm{P}_{2}$ \\
\hline 1 & 14731 & 14788 & -57 & & $31 \%{ }^{3} P_{0}+16 \%{ }^{1} G_{4}+14 \%{ }^{3} F_{4}$ \\
\hline 4 & 14854 & & & & $48 \%{ }^{1} \mathrm{D}_{2}+38 \%{ }^{3} \mathrm{P}_{2}$ \\
\hline 5 & 14939 & 14928 & 11 & $-1,89$ & $49 \%{ }^{1} \mathrm{D}_{2}+33 \%{ }^{3} \mathrm{P}_{2}+12 \%{ }^{3} \mathrm{~F}_{2}$ \\
\hline 1 & 15269 & & & & $31 \%{ }^{1} \mathrm{D}_{2}+23 \%{ }^{3} \mathrm{P}_{2}+22 \%{ }^{3} \mathrm{P}_{0}$ \\
\hline 1 & 15397 & 15388 & 9 & & $37 \%{ }^{3} P_{0}+33 \%{ }^{3} F_{4}+22 \%{ }^{1} G_{4}$ \\
\hline 5 & 15566 & 15529 & 37 & 0,93 & $47 \%{ }^{3} \mathrm{~F}_{4}+46 \%{ }^{1} \mathrm{G}_{4}$ \\
\hline 2 & 15824 & & & & $52 \%{ }^{1} \mathrm{G}_{4}+38 \%{ }^{3} \mathrm{~F}_{4}$ \\
\hline 4 & 15987 & & & & $50 \%{ }^{1} \mathrm{G}_{4}+43 \%{ }^{3} \mathrm{~F}_{4}$ \\
\hline 1 & 16319 & 16325 & -6 & & $50 \%{ }^{1} \mathrm{G}_{4}+40 \%{ }^{3} \mathrm{~F}_{4}$ \\
\hline 5 & 16351 & 16290 & 61 & 3,01 & $51 \%^{1} \mathrm{G}_{4}+42 \%{ }^{3} \mathrm{~F}_{4}$ \\
\hline 3 & 16703 & & & & $55 \%{ }^{1} \mathrm{G}_{4}+38 \%{ }^{3} \mathrm{~F}_{3}$ \\
\hline
\end{tabular}


Table VI (continued).

\begin{tabular}{|c|c|c|c|c|c|}
\hline$\Gamma$ & $E_{\text {calc. }}\left(\mathrm{cm}^{-1}\right)$ & $E_{\text {obs. }}\left(\mathrm{cm}^{-1}\right)$ & $\Delta E\left(\mathrm{~cm}^{-1}\right)$ & $g_{\text {calc. }}$ & Eigenvectors $\left(^{*}\right)$ \\
\hline $\begin{array}{l}2 \\
5 \\
1 \\
5 \\
3 \\
2 \\
5 \\
4 \\
5 \\
1 \\
3 \\
4 \\
3 \\
5 \\
1 \\
4 \\
1\end{array}$ & $\begin{array}{l}17603 \\
17847 \\
19548 \\
19558 \\
19595 \\
20293 \\
20339 \\
20564 \\
20838 \\
20894 \\
21103 \\
21205 \\
21913 \\
22344 \\
22647 \\
22654 \\
38406\end{array}$ & $\begin{array}{l}17804 \\
19556 \\
20324\end{array}$ & $\begin{array}{r}14 \\
-22\end{array}$ & $\begin{array}{r}-\quad 2,98 \\
0,51 \\
-\quad 3,69 \\
-\quad 2,68\end{array}$ & 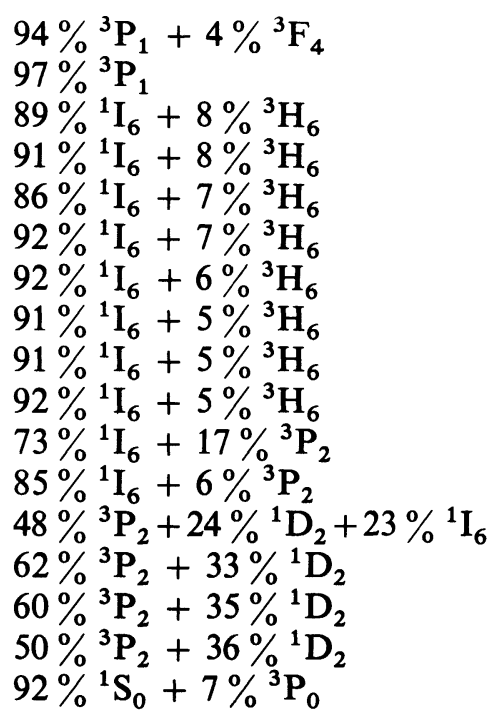 \\
\hline
\end{tabular}

$\left({ }^{\times}\right)$Eigenvectors are given with the percentage of each SLJ level.

$\left(^{*}\right)$ From fluorescence.

Table VII. - Calculated and experimental energy levels of $\mathrm{ThCl}_{4}-\mathrm{U}^{4+}$ in $\mathrm{D}_{2}$ symmetry with the main components (in squared \%) of the corresponding eigenvectors.

\begin{tabular}{|c|c|c|c|l|}
\hline$\Gamma$ & $E_{\text {calc. }}\left(\mathrm{cm}^{-1}\right)$ & $E_{\text {obs. }}\left(\mathrm{cm}^{-1}\right)$ & $\Delta E\left(\mathrm{~cm}^{-1}\right)$ & \multicolumn{1}{|c|}{ Main ${ }^{2 S+1} L_{\mathrm{J}}$ components } \\
\hline 2 & 0 & 0 & 0 & $88.9 \%{ }^{3} \mathrm{H}_{4}$ \\
3 & 104.0 & 57 & 47 & $87.7 \%{ }^{3} \mathrm{H}_{4}$ \\
4 & 215.6 & 134 & 81.6 & $86.6 \%{ }^{3} \mathrm{H}_{4}$ \\
1 & 227.3 & & & $85.9 \%{ }^{3} \mathrm{H}_{4}$ \\
1 & 834.6 & & $88.7 \%{ }^{3} \mathrm{H}_{4}$ \\
2 & 938.6 & & $84.2 \%{ }^{3} \mathrm{H}_{4}$ \\
1 & 1054.9 & & $87.7 \%{ }^{3} \mathrm{H}_{4}$ \\
3 & 1158.4 & & & $88.8 \%{ }^{3} \mathrm{H}_{4}$ \\
4 & 1224.2 & & & $88.4 \%{ }^{3} \mathrm{H}_{4}$ \\
1 & 3826.2 & & $80.5 \%{ }^{3} \mathrm{~F}_{2}$ \\
3 & 3973.5 & & $75.4 \%{ }^{3} \mathrm{~F}_{2}$ \\
4 & 4039.3 & & & $76.3 \%{ }^{3} \mathrm{~F}_{2}$ \\
2 & 4120.6 & & & $84.8 \%{ }^{3} \mathrm{~F}_{2}$ \\
1 & 4272.1 & & & $80.4 \%{ }^{3} \mathrm{~F}_{2}+12.5 \%{ }^{1} \mathrm{D}_{2}$ \\
1 & 5712.6 & & & $96.7 \%{ }^{3} \mathrm{H}_{5}$ \\
4 & 5804.7 & & & $84.6 \%{ }^{3} \mathrm{H}_{5}$ \\
3 & 5814.6 & 5815 & -0.4 & $78.6 \%{ }^{3} \mathrm{H}_{5}$ \\
2 & 5866.2 & & & $95.6 \%{ }^{3} \mathrm{H}_{5}$ \\
2 & 6370.9 & 6412 & -41.1 & $83.7 \%{ }^{3} \mathrm{H}_{5}$ \\
4 & 6430.6 & & & $93.5 \%{ }^{3} \mathrm{H}_{5}$ \\
3 & 6469.7 & 6524 & -54.3 & $82.5 \%{ }^{3} \mathrm{H}_{5}$ \\
4 & 6600.3 & & & $82.7 \%{ }^{3} \mathrm{H}_{5}$ \\
3 & 6655.5 & 6589 & 66.5 & $93.5 \%{ }^{3} \mathrm{H}_{5}$ \\
1 & 6698.3 & & & $85.3 \%{ }^{3} \mathrm{H}_{5}$ \\
2 & 6732.7 & & & $94.1 \%{ }^{3} \mathrm{H}_{5}$
\end{tabular}


Table VII (continued).

\begin{tabular}{|c|c|c|c|c|}
\hline$\Gamma$ & $E_{\text {calc. }}\left(\mathrm{cm}^{-1}\right)$ & $E_{\text {obs. }}\left(\mathrm{cm}^{-1}\right)$ & $\Delta E\left(\mathrm{~cm}^{-1}\right)$ & Main ${ }^{2 S+1} L_{\mathrm{J}}$ components \\
\hline 3 & 8419.5 & & & $77.7 \%{ }^{3} \mathrm{~F}_{3}$ \\
\hline 4 & 8433.1 & & & $86.2 \%{ }^{3} \mathrm{~F}_{3}$ \\
\hline 1 & 8520.3 & & & $91.4 \%{ }^{3} \mathrm{~F}_{3}$ \\
\hline 2 & 8541.5 & & & $90.2 \%{ }^{3} \mathrm{~F}_{3}$ \\
\hline 2 & 8616.4 & & & $78.3 \%{ }^{3} \mathrm{~F}_{3}$ \\
\hline 3 & 8672.1 & 8628 & 44.1 & $77.3 \%{ }^{3} \mathrm{~F}_{3}$ \\
\hline 4 & 8699.4 & 8705 & -5.6 & $73.8 \%{ }^{3} \mathrm{~F}_{3}$ \\
\hline 1 & 8828.3 & 8843 & -14.7 & $43.1 \%{ }^{3} \mathrm{~F}_{4}+23 \%{ }^{1} \mathrm{G}_{4}$ \\
\hline 3 & 8960.1 & & & $29.8 \%{ }^{3} \mathrm{~F}_{4}+23.6 \%{ }^{1} \mathrm{G}_{4}$ \\
\hline 4 & 9009.8 & & & $29.4 \%{ }^{3} \mathrm{~F}_{4}+23.8 \%{ }^{1} \mathrm{G}_{4}$ \\
\hline 2 & 9035.9 & & & 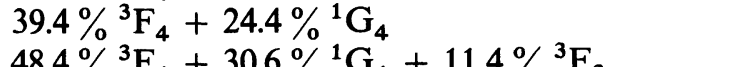 \\
\hline 2 & 9308.5 & & & $48.4 \%{ }^{3} \mathrm{~F}_{4}+30.6 \%{ }^{1} \mathrm{G}_{4}+11.4 \%{ }^{3} \mathrm{~F}_{3}$ \\
\hline 1 & $\begin{array}{l}9450.8 \\
96707\end{array}$ & 9405 & 45.8 & $\begin{array}{l}55.2 \%{ }^{3} \mathrm{~F}_{4}+32.8 \%{ }^{1} \mathrm{G}_{4} \\
55.8 \%{ }^{3} \mathrm{~F}_{4}+30.8 \%{ }^{1} \mathrm{G}_{4}\end{array}$ \\
\hline $\begin{array}{l}1 \\
4\end{array}$ & $\begin{array}{l}9670.7 \\
9697.8\end{array}$ & 9737 & -39.2 & $\begin{array}{l}55.8 \%{ }^{1} F_{4}+30.8 \%{ }^{1} G_{4} \\
50 . \overline{4} \%{ }^{3} F_{4}+21.6 \%{ }^{1} G_{4}\end{array}$ \\
\hline 3 & 9707.2 & 9762 & -54.8 & $32.8 \%{ }^{3} \mathrm{~F}_{4}+20.6 \%{ }^{1} \mathrm{G}_{4}$ \\
\hline 2 & 10750.7 & & & $81.3 \%{ }^{3} \mathrm{H}_{6}$ \\
\hline 1 & 10771.4 & & & $84.3 \%{ }^{3} \mathrm{H}_{6}$ \\
\hline 3 & 10809.9 & 10752 & 57.9 & $91.8 \%{ }^{3} \mathrm{H}_{6}$ \\
\hline 4 & 10822.2 & 10820 & -2.2 & $82.3 \%{ }^{3} \mathrm{H}_{6}$ \\
\hline 1 & 11268.4 & & & $88.4 \%{ }^{3} \mathrm{H}_{6}$ \\
\hline 3 & 11293.7 & & & $83.7 \%{ }^{3} \mathrm{H}_{6}$ \\
\hline 4 & 11373.2 & & & $76.1 \%{ }^{3} \mathrm{H}_{6}$ \\
\hline 2 & 11416.2 & & & $78.9 \%{ }^{3} \mathrm{H}_{6}$ \\
\hline 1 & 11437.2 & & & $79.5 \%{ }^{3} \mathrm{H}_{6}$ \\
\hline 2 & 11459.8 & & & $83.4 \%{ }^{3} \mathrm{H}_{6}$ \\
\hline 1 & 11751.1 & & & $81.7 \%{ }^{3} \mathrm{H}_{6}$ \\
\hline 3 & 11883.6 & & & $80.3 \%{ }^{3} \mathrm{H}_{6}$ \\
\hline 4 & 11950.8 & & & $74.3 \%{ }^{3} \mathrm{H}_{6}$ \\
\hline 1 & 14630.3 & 14608 & 22.3 & $40.2 \%{ }^{1} \mathrm{D}_{2}+20.8 \%{ }^{3} \mathrm{P}_{2}$ \\
\hline 2 & 14735.6 & 14787 & -51.4 & $21.6 \%{ }^{3} P_{0}+13.4 \%{ }^{1} D_{2}+10 \%{ }^{3} P_{2}$ \\
\hline 1 & 14874.9 & 14800 & 74.9 & $47.4 \%{ }^{1} \mathrm{D}_{2}+38 \%{ }^{3} \mathrm{P}_{2}$ \\
\hline 4 & 14886.0 & 14872 & -14 & $47.4 \%{ }^{1} \mathrm{D}_{2}+31 \%{ }^{3} \mathrm{P}_{2}$ \\
\hline 3 & 14980.5 & 14975 & 5.5 & $49 \%{ }^{1} \mathrm{D}_{2}+33.2 \%{ }^{3} \mathrm{P}_{2}$ \\
\hline 1 & 15256.6 & & & $30.5 \%{ }^{1} \mathrm{D}_{2}+23 \%{ }^{3} \mathrm{P}_{2}+19.5 \%{ }^{3} \mathrm{P}_{0}+9.5 \%{ }^{1} \mathrm{G}_{4}$ \\
\hline 1 & 15393.5 & 15399 & -5.5 & $41.5 \%{ }^{3} \mathrm{P}_{0}+24.1 \%{ }^{3} \mathrm{~F}_{4}+17.9 \%{ }^{1} \mathrm{G}_{4}$ \\
\hline 3 & 15526.8 & 15528 & -1.2 & $46.8 \%{ }^{3} \mathrm{~F}_{4}+27.8 \%{ }^{1} \mathrm{G}_{4}$ \\
\hline 4 & 15552.7 & 15538 & 14.7 & $31 \%{ }^{3} \mathrm{~F}_{4}+29.4 \%{ }^{1} \mathrm{G}_{4}$ \\
\hline 2 & 15816.5 & & & $51.6 \%{ }^{1} \mathrm{G}_{4}+37.8 \%{ }^{3} \mathrm{~F}_{4}$ \\
\hline 1 & 15951.5 & & & $49.8 \%{ }^{1} \mathrm{G}_{4}+42.8 \%{ }^{3} \mathrm{~F}_{4}$ \\
\hline 2 & 16320.4 & 16282 & 38.4 & $50 \%{ }^{1} \mathrm{G}_{4}+25.4 \%{ }^{3} \mathrm{~F}_{4}$ \\
\hline 4 & 16332.0 & 16325 & 7 & $47 \%{ }^{1} \mathrm{G}_{4}+38.4 \%^{3} \mathrm{~F}_{4}$ \\
\hline 3 & 16412.0 & 16303 & 109 & $33.2 \%{ }^{1} \mathrm{G}_{4}+26 \%^{3} \mathrm{~F}_{4}$ \\
\hline 1 & 16727.8 & & & $52.2 \%{ }^{1} \mathrm{G}_{4}+35.6 \%{ }^{3} \mathrm{~F}_{4}$ \\
\hline 2 & 17632.7 & 17675 & -42.3 & $93.1 \%{ }^{3} \mathrm{P}_{1}$ \\
\hline 4 & 17829.2 & 17789 & 40.2 & $97.4 \%{ }^{3} \mathrm{P}_{1}$ \\
\hline 3 & 17878.3 & 17814 & 64.3 & $97.3 \%{ }^{3} \mathrm{P}_{1}$ \\
\hline 1 & 19549.4 & & & $83.3 \%{ }^{1} \mathrm{I}_{6}$ \\
\hline 3 & 19551.3 & 19541 & 11.7 & $86 \%{ }^{1} \mathrm{I}_{6}$ \\
\hline 4 & 19579.5 & 19572 & 8.5 & $88.8 \%{ }^{1} \mathrm{I}_{6}$ \\
\hline 1 & 19607.6 & & & $81.1 \%{ }^{1}{ }^{1} \mathrm{I}_{6}$ \\
\hline 4 & 20266.4 & & & $82.3 \%{ }^{1} \mathrm{I}_{6}$ \\
\hline 2 & 20292.6 & & & $84.7 \%{ }^{1} \mathrm{I}_{6}$ \\
\hline 3 & 20478.1 & & & $88.9 \%{ }^{1} \mathrm{I}_{6}$ \\
\hline
\end{tabular}


Table VII (continued).

\begin{tabular}{|c|c|c|c|l|}
\hline$\Gamma$ & $E_{\text {calc. }}\left(\mathrm{cm}^{-1}\right)$ & $E_{\text {obs. }}\left(\mathrm{cm}^{-1}\right)$ & $\Delta E\left(\mathrm{~cm}^{-1}\right)$ & \multicolumn{1}{|c|}{ Main ${ }^{2 S+1} L_{\mathrm{J}}$ components } \\
\hline 2 & 20657.6 & & & $81.6 \%{ }^{1} \mathrm{I}_{6}$ \\
3 & 20860.7 & & & $92 \%{ }^{1} \mathrm{I}_{6}$ \\
4 & 20939.1 & & $87.9 \%{ }^{1}{ }^{1} \mathrm{I}_{6}$ \\
1 & 20986.8 & & $89.2 \%{ }^{1} \mathrm{I}_{6}$ \\
1 & 21144.2 & & $50.2 \%{ }^{1} \mathrm{I}_{6}$ \\
2 & 21231.4 & & $82.8 \%{ }^{1} \mathrm{I}_{6}$ \\
1 & 21914.1 & & & $46 \%{ }^{3} \mathrm{P}_{2}+23 \%{ }^{1} \mathrm{I}_{6}+22.6 \%{ }^{1} \mathrm{D}_{2}$ \\
4 & 22307.4 & 22280 & 27.4 & $60 \%{ }^{3} \mathrm{P}_{2}+32.5 \%{ }^{1} \mathrm{D}_{2}$ \\
3 & 22386.7 & 22330 & 56.7 & $62 \%{ }^{3} \mathrm{P}_{2}+33.2 \%{ }^{1} \mathrm{D}_{2}$ \\
1 & 22653.5 & 22705 & 51.5 & $58.6 \%{ }^{3} \mathrm{P}_{2}+34.8 \%{ }^{1} \mathrm{D}_{2}$ \\
2 & 22695.2 & & & $48.8 \%{ }^{3} \mathrm{P}_{2}+35.6 \%{ }^{1} \mathrm{D}_{2}$ \\
1 & 38358.8 & & & $92.4 \%{ }^{1} \mathrm{~S}_{0}$ \\
\hline
\end{tabular}

can be introduced to measure the relative strength of the crystal field and table VIII shows their values for different compounds. $\mathrm{ThCl}_{4}-\mathrm{U}^{4+}$, as $\mathrm{ThBr}_{4}-\mathrm{U}^{4+}[1]$ is a system with a relatively weak crystal field, in comparison to $\mathrm{U}\left(\mathrm{BD}_{4}\right)_{4}$ [2] or $\mathrm{Cs}_{2} \mathrm{UCl}_{6}$ [18], and this results in a fitting with a reasonably small r.m.s. despite of the modulation of the matrix and the approximate symmetry $D_{2 d}$ used for $\mathrm{U}^{4+}$ in $\mathrm{ThCl}_{4}$. In the one hand, this weakness of the crystal field in $\mathrm{ThX}_{4}-\mathrm{U}^{4+}$ was a favourable element that permitted us to use the parameters of $\mathrm{ThBr}_{4}-\mathrm{U}^{4+}[1]$ as starting values in view of the similarity of the spectra of $\mathrm{U}^{4}$ in the tetrachloride and the tetrabromide. But on the other hand, instead of enhancing the possible variations from a bromide host to a chloride, the parameters in both hosts showed no systematic trend, whereas there is a clear decrease in the values of the free ion $F^{k}$ parameters for $\mathrm{U}^{4+}$ in borohydrides [2] compared to those in the thorium tetrahalides, which is due to covalent character of the hydrogen (deuterium) uranium bond compared to the much more ionic halide-uranium one.
Table VIII. - Values of the Auzel parameter for $\mathrm{U}^{4+}$ in different compounds (in $\mathrm{cm}^{-1}$ ).

\begin{tabular}{|c|c|c|c|c|}
\cline { 2 - 5 } \multicolumn{1}{c|}{} & $\mathrm{ThCl}_{4}-\mathrm{U}^{4+}$ & $\mathrm{ThBr}_{4}-\mathrm{U}^{4+}$ & $\mathrm{U}\left(\mathrm{BD}_{4}\right)_{4}$ & $\mathrm{Cs}_{2} \mathrm{UCl}_{6}$ \\
\hline$\frac{N_{\mathrm{v}}}{\sqrt{4 \pi}}$ & 1560 & 1544 & 3942 & 3325 \\
\hline
\end{tabular}

\section{Conclusions.}

The optical spectra of $\beta-\mathrm{ThCl}_{4}-\mathrm{U}^{4+}$ represent with $\beta-\mathrm{ThBr}_{4}-\mathrm{U}^{4+}$ [1] the only cases of an optically active ion $\mathrm{U}^{4+}\left(5 \mathrm{f}^{2}\right)$ fully studied in an incommensurately modulated structure. The spectroscopic identification of lines corresponding to $\mathrm{U}^{4}+$ in sites of $\mathrm{S}_{4}$ (approximated by $\mathrm{D}_{2 \mathrm{~d}}$ ) and $\mathrm{D}_{2}$ symmetries permitted us to propose a parametric analysis of $\mathrm{U}^{4+}$ in both symmetries. The results, comparable to those obtained for $\mathrm{ThBr}_{4}-\mathrm{U}^{4+}$ do not exhibit a systematic trend in the values of the parameters in passing from the bromide to the chloride. This fact could come from the relatively large deviations from the crystal field model for the actinides that would hide this effect when the coordination polyhedra of the actinide are too similar. 


\section{References}

[1] Delamoye, P., Rajnak, K., Genet, M., EdelsTEIN, N., Phys. Rev. B 28 (1983) 4923.

[2] RAJNAK, K., GAMP, E., SHINOMOTO, R., EDELSTEIn, N., J. Chem. Phys. 80 (12) (1984) 5942.

[3] Bernard, L., Currat, R., Delamoye, P., ZeYen, C. M. E., HuberT, S., DE KOUCHKOVSKY, R., J. Physique. C 16 (1983) 433.

[4] Delamoye, P., Bernard, L., Currat, R., Krupa, J. C., Petitgrand, G., Communication at the conference "Journées de l'état solide », Bordeaux, France, June 1984.

[5] Delamoye, P., Currat, R., J. Phys. Lett. 43 (1982) L-655.

[6] Krupa, J. C., Khan Malek, C., Delamoye, P., MoINE, B. and PEDRINI, C., to be published.

[7] Hussonnois, M., Krupa, J. C., Genet, M., BrilLARD, L., CARlier, R., J. Crystal Growth 51 (1981) 11.

[8] Mooney, R. C. L., Acta Cryst. 2 (1949) 189.

[9] Mason, J. T., Jha, M. C., ChiotTi, P., J. Less. Commun. Metals 34 (1973) 143.
[10] Khan Malek, C., Krupa, J. C., to be published.

[11] Koster, G. F., DimmoCK, J. O., WheEler, R. G., STATZ, H., properties of the thirty two point groups (M. I. P. Cambridge Mass) 1963.

[12] Esterowitz, L., Bartoli, J. F., Aller, R. E., WORTMAN, D. E., MORRISON, C. A., LEAWITT, R. P., Phys. Rev. B 19 (1979) 6442.

[13] Briat, B., Delamoye, P., Rivoal, J. C., Hubert, S., Evesque, P., J. Physique 46 (1985) 1375.

[14] Genet, M., Delamoye, P., Edelstein, N., Conway, J., J. Chem. Phys. 67 (1977) 1620.

[15] Flint, C. D., Tanner, P. A., Mol. Phys. 53 (1984) 429.

[16] HuFNER, S., Optical spectra of transparent rare earth compounds (Academic press, N. Y.) 1978.

[17] Auzel, F., Malta, O. L., J. Physique 44 (1983) 201.

[18] Johnston, D. R., Satten, R. A., Wrong, E., J. Chem. Phys. 44 (1966) 687.

[19] Van Deurzen, C. H. H., RajnaK, K., Conway, J. G., J. Opt. Soc. Am. B 1 (1984) 45. 